\title{
Population structure of Macrobrachium australiense (Decapoda: Palaemonidae) in Western Queensland, Australia: the role of contemporary and historical processes
}

\author{
G Carini and JM Hughes \\ Cooperative Research Centre for Freshwater Ecology, Centre for Riverine Landscapes, Griffith University, Nathan 4111, Queensland, \\ Australia
}

\begin{abstract}
Rivers of Western Queensland, Australia, represent a discontinuous and variable aquatic habitat for the freshwater fauna of the region. Rivers periodically fluctuate between being highly fragmented, with numerous disconnected waterholes and ephemeral channels, and being highly connected by a dominant system of anastomosing channels. We used mitochondrial sequences to investigate the genetic structure and inferred patterns of dispersal associated with this flow regime for the freshwater prawn, Macrobrachium australiense (Decapoda: Palaemonidae), sampling 28 localities throughout eight catchments. Based on a 505 base pair fragment of mitochondrial cytochrome $c$ oxidase subunit I, we identified 98 haplotypes in a sample of 402 individuals. The haplotypes clustered into two main clades correspond-
\end{abstract} Keywords: freshwater prawn; phylogeography; AMOVA; nested clade analysis; gene flow and dispersal

\section{Introduction}

Dispersal is the outward spreading of organisms from their point of origin and it can affect the evolution and population genetics of a species, only if successful colonisation is followed by breeding of subsequent generations. Dispersal is essential for the maintenance of gene flow and genetic diversity, and also for colonisation and re-colonisation of habitats. Generally, species with low dispersal capabilities exhibit a tendency towards genetic fragmentation and species with efficient mechanisms of dispersal have limited genetic structuring of their subpopulations (Slatkin, 1987).

Freshwater invertebrates occur in habitats that represent discrete sites surrounded by inhospitable terrestrial landscapes. Some aquatic insects possess a flying stage in their life cycle, which allows them to disperse across drainage boundaries (Hughes et al, 1998; Miller et al, 2002). However, movements of continuously aquatic freshwater species are very much limited by the physical nature and arrangement of the riverine system (Hurwood and Hughes, 2001; McGlashan and Hughes, 2001) and

Correspondence: G Carini, Cooperative Research Centre for Freshwater Ecology, Centre for Riverine Landscapes, Griffith University, Nathan 4111, Queensland, Australia. E-mail: g.carini@griffith.edu.au

Received 14 December 2003; accepted 20 April 2004; published online 25 August 2004 ing geographically to the major drainages: the Lake Eyre and Murray-Darling basins. Populations of $M$. australiense inhabiting the two basins appear to have diverged around 800000 years ago (estimated sequence divergence of $1.6 \%)$. Analysis of population differentiation indicated contemporary high levels of genetic subdivision and restricted gene flow among populations within and among catchments. Phylogenetic analysis detected a series of historical range expansions in the region and we suggest that climate fluctuations during the Pleistocene have resulted in extensive floods that have promoted historical movements of aquatic organisms across catchment boundaries.

Heredity (2004) 93, 350-363. doi:10.1038/sj.hdy.6800510

Published online 25 August 2004 
Notopala sublineata (Gastropoda: Viviparidae) (Carini and Hughes, in review). In addition, Hughes and Hillyer (2003) indicated high levels of dispersal and gene flow within catchments for the freshwater crayfish, but Carini and Hughes (in review) detected very low levels of gene flow and dispersal between populations both within and among catchments for the snails.

The freshwater prawn, Macrobrachium australiense (Decapoda: Palaemonidae), appears to have good dispersal capabilities as described by Williams (1980) and suggested by Cook et al (2002) in a recent study in Western Queensland. They used mostly allozyme analysis, although a fragment of the cytochrome oxidase I gene was sequenced for a small numbers of individuals. A major division between Lake Eyre and MurrayDarling basin was detected, but low levels of genetic differentiation between populations from the same catchment. Nevertheless, Hughes et al (in review) demonstrated that, using mtDNA markers, species with apparently efficient mechanisms of dispersal could display low levels of gene flow between populations within catchments in the same geographic region. Thus, our aim was to use mtDNA to investigate the genetic variation among populations of $M$. australiense and to infer contemporary levels of dispersal and gene flow in Western Queensland. Due to the haploid nature and the maternal mode of inheritance, mtDNA has a four-fold smaller effective population size than nuclear markers, increasing its sensitivity to any limited gene flow between populations (Birky et al, 1989). Therefore, it would be more likely to detect genetic structure of the species using mtDNA than allozymes.

In addition, by assessing information from rapidly evolving molecular markers, we intended to determine the extent to which the population structure of $M$. australiense in Western Queensland results from recurrent processes, such as ongoing gene flow, versus historical processes, such as fragmentation or range expansion (Templeton et al, 1995). Recent studies within the region (Hughes and Hillyer, 2003; Hughes et al, in review; Carini and Hughes, in review) have suggested that climate oscillations of the Pleistocene may be directly correlated with historical high levels of connectivity and therefore dispersal across catchment boundaries. We hypothesised that levels of connectivity and dispersal between populations of $M$. australiense might have been higher in ancient times.

\section{Materials and methods}

\section{Study area and sampling design}

Sampling sites are localised within the Lake Eyre basin and the northern regions of the Murray-Darling basin (Figure 1). The Lake Eyre basin is an endoreic system and it is characterised by temporary streams and rivers (Knighton and Nanson, 1994). All the catchments terminate at Lake Eyre except for the Bulloo, which terminates in a series of wetlands in northern New South Wales. The Murray-Darling basin is exoreic, drawing water from two major systems: the Murray and the Darling rivers, ultimately draining to the sea through river systems along the South Australian coast. Western Queensland rivers are not conventional systems due to their highly variable hydrology. During floods, dispersal presumably occurs not only 'upstream-downstream' but also laterally via the network of ephemeral channels because of the low topographic relief of the region and the intense water flow. We sampled $M$. australiense from waterholes in the four major catchments (Bulloo, Cooper, Diamantina and Georgina) and tributaries within the Lake Eyre basin as well as in four catchments (BalonneCondamine, Border rivers, Warrego and Paroo) and tributaries within the Murray-Darling basin. The freshwater prawns were caught using a hand-hauled seine net, placed in a liquid nitrogen container and then transferred into a $-80^{\circ} \mathrm{C}$ freezer, until required for further analysis.

\section{Study species: $M$. australiense}

The freshwater prawn family Palaemonidae is found throughout the world in a variety of habitats (Lee and Fielder, 1983). In particular, the genus Macrobrachium is widely distributed in Australia, but apparently only one species ( $M$. australiense) occurs in the arid and semiarid streams of Western Queensland (Williams, 1980). M. australiense is the most common and abundant macroinvertebrate species in these water systems (Lee and Fielder, 1983; Sheldon and Walker, 1998). It completes all the life stages in water, including a planktonic larval phase (Williams, 1980), but it does not possess any strategies, such as resistant eggs or ability to construct burrows, to overcome desiccation (Williams, 1980). M. australiense is thought to be able to disperse across terrestrial environments (Lee and Fielder, 1984). However, such terrestrial dispersal across watersheds seems to be unlikely in Western Queensland due to the extreme aridity of the region.

\section{Mitochondrial DNA extraction, PCR and sequencing}

Mitochondrial DNA was extracted from the muscle tissue of $M$. australiense using the alkaline lysis protocol outlined in Tamura and Aotsuka (1988). A 710 base pair fragment of mitochondrial DNA cytochrome $c$ oxidase subunit I (COI) was amplified using polymerase chain reaction (PCR) with primers LCO1490 and HCO2198 (Folmer et al, 1994). Reactions contained $0.5 \mu \mathrm{l}$ of $10 \mathrm{mM}$ dNTPs, $1.25 \mu \mathrm{l}$ of $50 \mathrm{mM} \mathrm{MgCl} 2,2.5$ of $10 \times$ polymerase reaction buffer, $0.1 \mu \mathrm{l}$ of Taq polymerase (Biotech International Limited), $1 \mu \mathrm{l}$ of each primer $(10 \mu \mathrm{M}), 4 \mu \mathrm{l}$ of mtDNA template and adjusted to a final volume of $25 \mu \mathrm{l}$ with $\mathrm{ddH}_{2} \mathrm{O}$. PCR was performed on the Geneamp PCR System 9700 (PE Applied Byosystem); DNA was initially denatured at $94^{\circ} \mathrm{C}$ for $5 \mathrm{~min}$, followed by 35 cycles of: denaturation at $94^{\circ} \mathrm{C}$ for $30 \mathrm{~s}$; annealing temperature at $55^{\circ} \mathrm{C}$ for $30 \mathrm{~s}$ and extension at $72^{\circ} \mathrm{C}$ for $45 \mathrm{~s}$. The final extension at $72^{\circ} \mathrm{C}$ for $7 \mathrm{~min}$ terminated each reaction. A negative control was always included to eliminate the possibility of contamination. PCR product was purified using a Quiaquick agarose gel purification kit (Quiagen Pty Ltd, Victoria, Australia) and directly sequenced on an automated 377 Applied Biosystems sequencer. Each individual was sequenced using LCOI 1490; a few samples per waterhole were sequenced in both directions to check sequence accuracy. Sequences were aligned using the SEQUENCHER ${ }^{\mathrm{TM}}$ package (1995, Gene Codes Corporation, Inc.). 


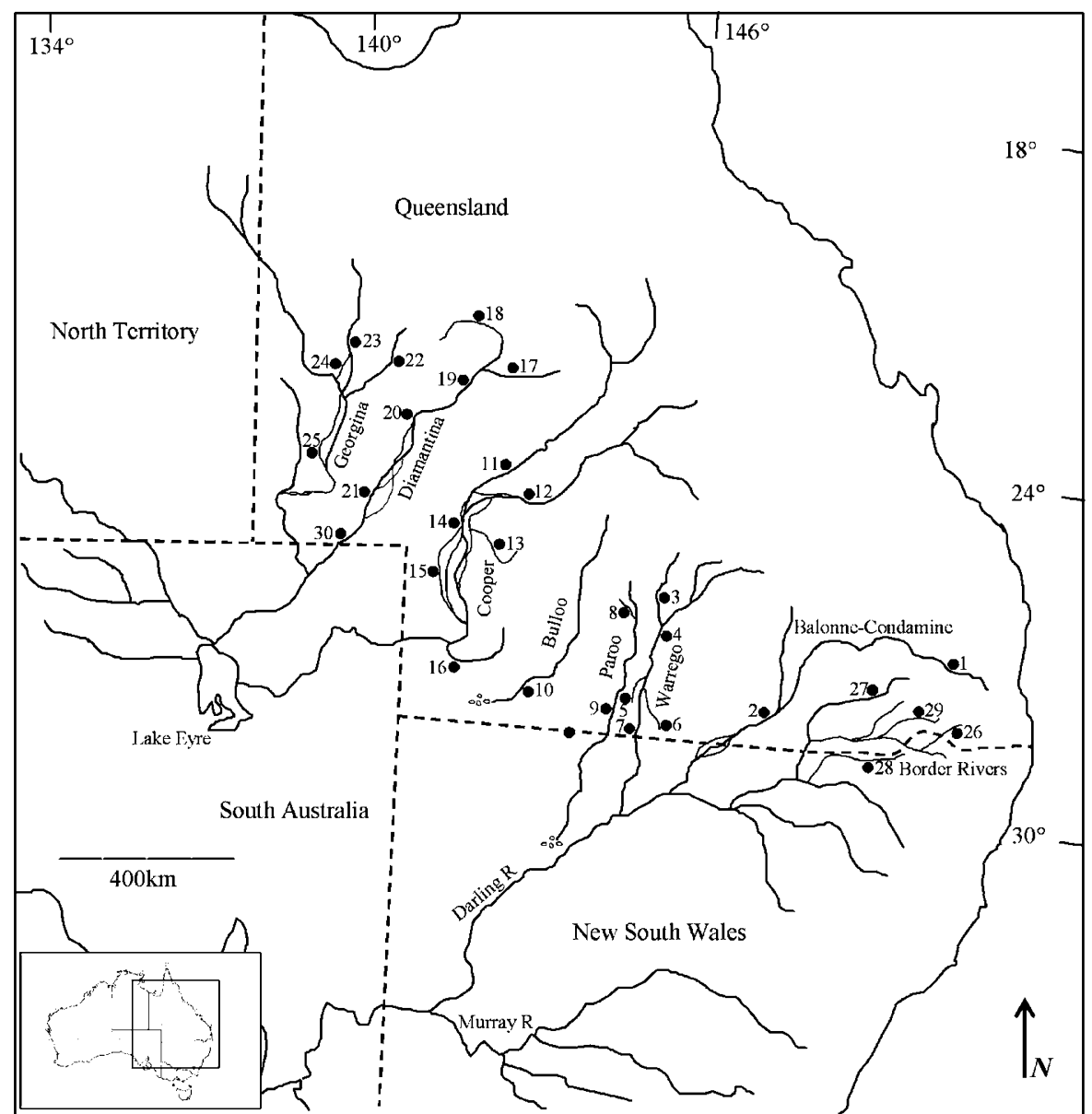

Figure 1 Study area and sampling sites for M. australiense. Site names and catchment groupings are: Georgina catchment: Hamilton river at Bulla Bulla waterhole (22), Georgina river at Boulia (23), Burke river at Boomerang waterhole (24), Eyre creek at Cuttaburra crossing (25); Diamantina catchment: Wockingham creek at Winton (17), Diamantina river at Combo waterhole (18), Diamantina river at Verdun Valley (19), Diamantina river at Diamantina Lakes (20), Diamantina river at Monkira (21); Cooper catchment: Thompson river at Noondah (11), Barcoo river at Retreat (12), Kyabra creek at Springfield (13), Cooper creek at Windorah (14), Cooper creek at Tanbar (15), Wilson river at Noccundra (16); Bulloo catchment: Bulloo river at Thargomindah (10); Paroo catchment: Paroo river at Cheepie (8), Paroo river at Eulo (9); Warrego catchment: Ward river at Charleville (3), Warrego river at Quilberry (4), Warrego river at Glencoe (5), Warrego river at Thurulgoona (6), Cuttaburra creek at Tinnenburra (7); Balonne-Condomine catchment: Condomine river at Brigalow (1), Balonne river at St George (2); Border Rivers catchment: Whalan creek at Salt Bush (26), Weir river at Kanowna (29), Gnungarah creek at Gnungarah (28) and Commoron creek at Iron Bark (28).

\section{Genetic variability}

Cytochrome $c$ oxidase subunit I (COI) is a mitochondrial coding gene, so we tested for its neutrality prior to genetic analysis. We performed Tajima's $D$ test for selective neutrality (1989) in the program Arlequin version 2.0 (Schneider et al, 2000). Molecular diversity estimates were calculated using the package Arlequin version 2.0 (Schneider et al, 2000).

\section{Population structure}

The spatial distribution of genetic variation was examined using an analysis of molecular variance (AMOVA; Excoffier et al, 1992) and nested clade analysis (NCA; Templeton et al, 1995). AMOVA was performed to test the null hypothesis that genetic variation was not associated with drainage structure, using Arlequin version 2.0 software (Schneider et al, 2000). Ф-Statistics (based on haplotype frequencies and molecular divergence) and Fstatistics (haplotype frequencies only) were used to assess population subdivision. Hierarchical partitioning was calculated between and within the two drainages: Lake Eyre basin and Murray-Darling basin. In addition, separate hierarchical AMOVAs were calculated within and among catchments for both the Lake Eyre and Murray-Darling basins. Significance was tested using a nonparametric permutation procedure (Excoffier et al, 1992), incorporating 10000 permutations.

\section{Phylogeographic analysis}

Nested clade analysis was used to test the null hypothesis of no association between clades and geographic locations. We constructed a haplotype network displaying evolutionary relationships among sampled haplotypes using the program TCS 1.13 (Clement et al, 2000), which incorporates the cladogram algorithm described by Templeton et al (1992). The nesting information, sample size for each haplotype and geographical location of each clade were then entered into the software 
package GeoDis 2.0 (Posada et al, 2000). Where significance was detected, we used the updated version (2001) of the Inference Key by Templeton (1998) to determine the likely cause of the association (downloaded from the Crandall home page: http://inbio. byu.edu/faculty/kac/crandall_lab/Computer.html

We analysed pairwise migration rates and divergence times between populations with a coalescent-based approach using the program MDIV (Nielsen, 2002). MDIV is a program that simultaneously estimates divergence times and migration rates between two populations. We chose to run the program under the 'finite model', which does not assume that only one mutation occurs at each site but takes into account the possibility of multiple hits, differences in the nucleotide frequencies and the presence of transition/transversion bias (Nielsen and Wakeley, 2001). MDIV estimated values for theta $\left(\theta=2 N_{e f} u\right)$, migration rate $\left(M=2 N_{e f} m\right)$, time of population divergence $\left(T=t / N_{e f}\right)$ and expected time to the most common ancestor $(\mathrm{TMRCA}=t u)($ Nielsen and Wakeley, 2001). We then ran each simulation $5 \times 10^{6}$ times with a $10 \%$ burn-in period as suggested by Nielsen (2002). Likelihood values for $\theta, M$ and $T$ were calculated and the value with the highest posterior probability accepted as the best estimate. Values for $T$ and TMRCA were calculated using a generation time of 1 year (Williams, 1980) and a mutation rate estimated at $6 \times 10^{-6}$ substitutions/locus/year (Shank et al, 1999).

\section{Results}

Our mitochondrial data did not deviate significantly from predictions of neutrality (Tajima's $D$ : -1.02079 ; $P=0.14$; Tajima, 1989). We acquired sequence data for 402 specimens of $M$. australiense collected from eight catchments, using direct sequencing. Based on a 505 base pair fragment of COI of unambiguous sequence, we identified 98 unique haplotypes (Appendices 1-3), of which $63 \%$ represented single individuals. Of the 505 base pairs sequenced, 76 (15\%) sites were polymorphic. The transition (Ts) to transversion (Tv) substitution ratio was 5.3:1. Haplotype gene diversity values (mean: $0.923 \pm 0.0075)$ were high and variable; reflecting the large number of haplotypes detected at most sites.

\section{Population structure}

Analysis of molecular variance of a total of $402 \mathrm{M}$. australiense samples detected significant levels of genetic variation at all the spatial scales examined and no haplotypes were shared between the two basins. There were highly significant levels of genetic differentiation of populations between and within the major drainages and among all catchments (Table 1). Within the Lake Eyre basin, we detected significant levels of genetic differentiation of populations between the two groups formed by adjacent catchments: Cooper-Bulloo and Diamantina-Georgina. Also, we observed significant values among and within the four catchments (Table 2). Within the Murray-Darling basin, estimates of the genetic variation were significant among populations within catchments, but not significant among the four catchments $\left(\Phi_{\mathrm{CT}}: 0.04805 ; P=0.16 \pm 0.0043\right)$ (Table 3). Moreover, within the Murray-Darling basin, the estimate of $\Phi_{\mathrm{SC}}$ was higher than $\Phi_{\mathrm{CT}}$, suggesting that genetic variation is higher between populations within catch-
Table 1 Results of the analysis of molecular variance for populations of Macrobrachium australiense, displaying F-statistics and $\Phi$-statistics

\begin{tabular}{llc}
\hline Level of partitioning & F-statistics & $\Phi$-statistics \\
\hline $\begin{array}{l}\text { Among drainages } \\
\text { (Lake Eyre Basin) (Murray-Darling }\end{array}$ & $F_{\mathrm{CT}}: 0.139^{*}$ & $\Phi_{\mathrm{CT}}: 0.84254^{*}$ \\
Basin) & & \\
$\begin{array}{l}\text { Among Catchments } \\
\text { (Cooper) (Diamantina) (Georgina) }\end{array}$ & $F_{\mathrm{CT}}: 0.24^{*}$ & $\Phi_{\mathrm{CT}}: 0.80559^{*}$ \\
$\begin{array}{l}\text { (Bulloo) (Paroo) } \\
\text { (Balonne-Condomine) (Warrego) } \\
\text { (Border Rivers) }\end{array}$ & & \\
\hline
\end{tabular}

The levels of partitioning investigated included: between the two drainages, the Lake Eyre Basin and the Murray-Darling, and also, among all the eight catchments, ${ }^{*} P<0.001$.

Table 2 Results of the analysis of molecular variance for populations of Macrobrachium australiense, displaying the F-statistics and $\Phi$-statistics

\begin{tabular}{llr}
\hline Level of partitioning & F-statistics & Ф-statistics \\
\hline $\begin{array}{l}\text { Among groups within Lake Eyre } \\
\text { Basin }\end{array}$ & $F_{\mathrm{CT}}: 0.288^{*}$ & $\Phi_{\mathrm{CT}}: 0.387^{*}$ \\
(Cooper-Bulloo) (Diamantina- & & \\
Georgina) & &
\end{tabular}

Among Catchments within Lake $F_{\mathrm{CT}}: 0.295^{*} \quad \Phi_{\mathrm{CT}}: 0.41128^{*}$ Eyre Basin (Cooper) (Diamantina) (Georgina) (Bulloo)

Among populations within

$F_{\text {SC }}: 0.032^{*} \quad \Phi_{\text {SC }}: 0.06393^{*}$ catchments

The levels of partitioning investigated included: between the groups correspondent to adjacent catchments (Bulloo-Cooper and Diamantina-Georgina) and among and within the four catchments of the Lake Eyre Basin, ${ }^{*} P<0.001$.

Table 3 Results of the analysis of molecular variance for populations of Macrobrachium australiense, displaying the percentage variation and associated $\Phi$-statistics and the F-statistics

\begin{tabular}{llr}
\hline Level of partitioning & F-statistics & Ф-statistics \\
\hline Among catchments within Murray- & $F_{\mathrm{CT}}: 0.042$ & $\Phi_{\mathrm{CT}}: 0.04805$ \\
$\begin{array}{l}\text { Darling Basin } \\
\text { (Paroo) (Balonne-Condomine) }\end{array}$ & & \\
(Warrego) (Border Rivers) & &
\end{tabular}

Among populations within

$F_{\mathrm{SC}}: 0.155^{*} \quad \Phi_{\mathrm{SC}}: 0.12058^{*}$ catchments

The levels of partitioning investigated included: among and within the four catchments of the Murray-Darling Basin. ${ }^{*} P<0.001$.

ments than between catchments overall (Table 3). This result seems to be largely due to the fact that the population from the Glencoe site in the Warrego (number 5 in Figure 1) did not share any haplotypes with other populations from the same catchment (Appendix 3). Indeed, when the Glencoe site was removed from the analyses, both $\Phi_{\mathrm{SC}}$ and $F_{\mathrm{SC}}$ were not significant and lower than $\Phi_{\mathrm{CT}}$ and $F_{\mathrm{CT}}$, respectively $\left(\Phi_{\mathrm{CT}}\right.$ : $0.0985^{*}$ and 
$F_{\mathrm{CT}}: 0.1267^{*}, P<0.001 ; \Phi_{\mathrm{SC}}: 0$ and $F_{\mathrm{SC}}: 0.02583$, not significant).

\section{Phylogeographic structure and NCA}

It was evident that the haplotype network was divided into two distinct groups corresponding to the Lake Eyre and Murray-Darling basins. The Murray-Darling clade was more closely related to the Diamantina-Georgina clade than to the Cooper clade (Figure 2, Appendix 2 and 3).

Within the Lake Eyre basin, two further groups could be distinguished. The first group contained mostly samples collected in the Diamantina, the Georgina and the Bulloo catchments (Figure 1), but a single haplotype (H-2) was also found in the Cooper catchment. The network indicated that haplotype 2 was at the centre of this group (Figure 2 and Appendix 2). The second group included haplotypes from throughout the Cooper catchment. Haplotype 37 was the centre of this group and was detected in all sites with the exception of the Wilson river at Noccundra (Figure 1 and Appendix 2). The Wilson river population (site number 16 in Figure 1) represented a unique subclade.

The group represented by the Murray-Darling haplotypes was complex and there was no clear grouping of samples according to catchments. In fact, there was extensive haplotype sharing between waterholes among adjacent and nonadjacent catchments. Haplotypes 90 and 76 were internal to the network and widespread across the Murray-Darling basin. Haplotype 76 occurred in the Warrego, Border rivers and Balonne-Condamine catchments, while haplotype 90 was widespread across all the catchments within the Murray-Darling basin (Figure 2 and Appendix 3), except for the population of Glencoe in the Warrego (site number 5 in Figure 1). In fact, samples from this population contained a unique subclade (Appendix 3).

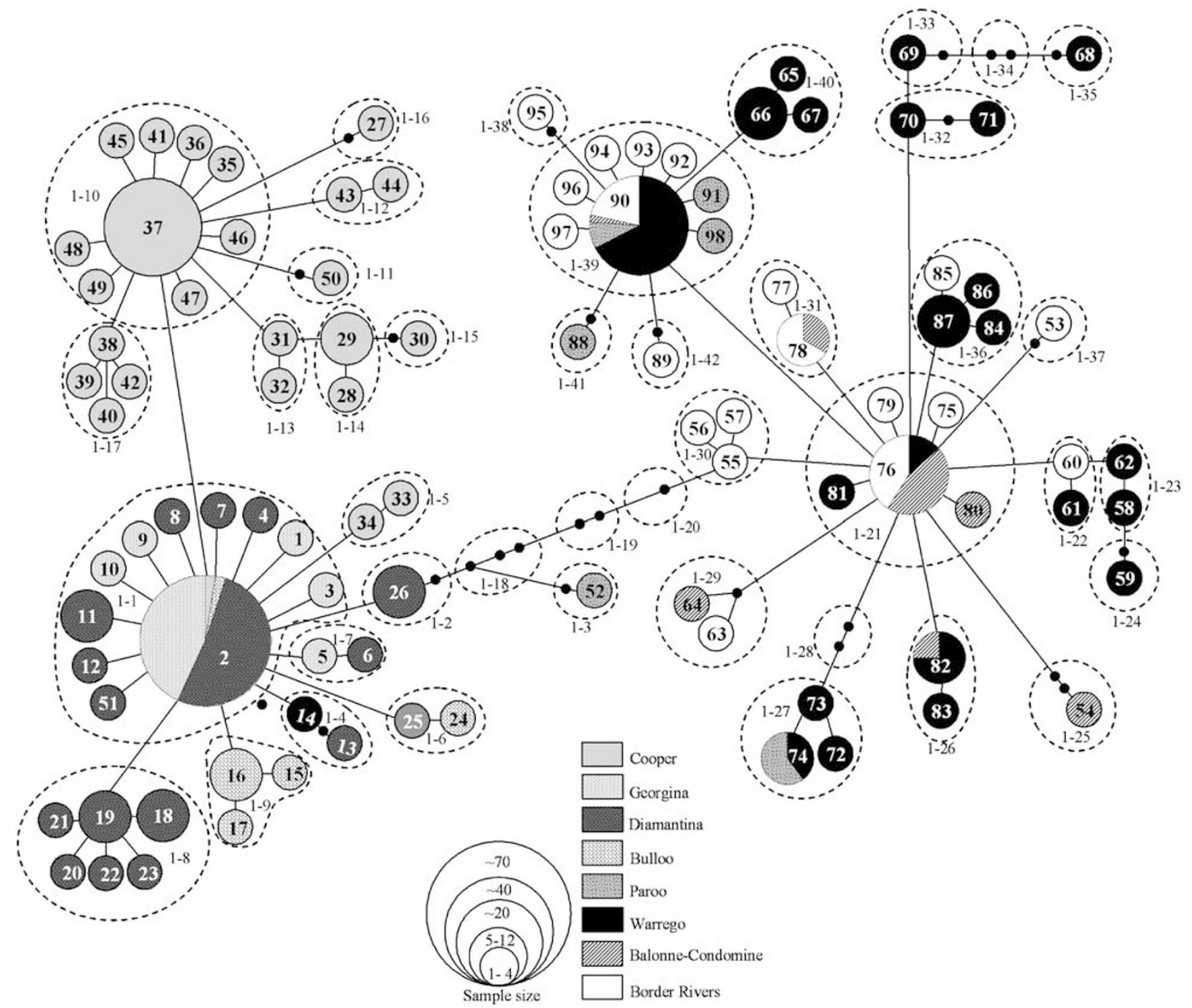

Figure 2 Haplotype and genealogy network, indicating the catchment distribution of each haplotype (1-98). Circle size for each haplotype is proportional to the overall frequency in our sample. Note that proportions of colours corresponding to catchment, within each pie chart, are representative of the relative number of that haplotype from each catchment. Haplotypes not detected in the sample are indicated by a small solid black circle. 
The 98 haplotypes were partitioned into 42 one-step clades, 11 two-step clades, four three-step clades and two four-step clades (Figures 2 and 3). The haplotype cladogram revealed two divergent clades: 4-1 and 4-2 (Figure 2). Haplotypes within clade 4-1 (3-2 and 3-1) belonged to the Lake Eyre basin, whereas haplotypes within clade 4-2 (3-3 and 3-4) belonged to the MurrayDarling basin (Figure 2, and Appendices 2 and 3). The level of genetic divergence between these clades was approximately $1.6 \%$ (uncorrected $P$-distance).

Contingency analyses indicated no significant associations between nested clades and geography $(P>0.05)$ for any one-step clades, except 1-36 (Table 4). The Inference Key (Templeton, 1998) indicated a pattern of geographic variation in clade 2-11 (from the Murray-Darling basin) consistent with restricted gene flow with isolation by distance. For clades 2-1 and 2-3 (from the Diamantina/ Georgina and Cooper, respectively), range expansion with long distance colonisation was suggested. Contiguous range expansion was indicated for clade 3-3 (from the Murray-Darling). Range expansion with long-distance colonisation was suggested for clade 4-1 (from the Lake Eyre basin) and restricted gene flow with isolation by distance was indicated for clade 4-2 (from the Murray-Darling). The outcome for the total cladogram was inconclusive (Figure 3 and Table 4).

One population of approximately 10-15 sequences was randomly chosen from each catchment and we estimated values for $\theta, M, T$, and TMRCA for 28 sets of pairwise comparisons. Estimates based on time since the populations have diverged $(T)$ ranged between roughly 30000 years ago for populations from different catchments of the Murray-Darling basin to around 800000 years ago for populations from the two major basins.

It was estimated that, within the Lake Eyre basin, populations in different catchments became separated between 260000 and 50000 years ago. Populations from catchments within the Murray-Darling appeared to have been separated more recently, between 80000 and 13000 years ago (Table 5).

Estimates of gene flow based on migration rate $(M)$ between populations from the two major basins and between those within the Lake Eyre basin were very low. Estimates of $M$ between populations from the MurrayDarling were low to moderate, ranging from a value of 1.24 (between the Border Rivers and the Paroo catchments) to 23.25 (between the Warrego and the BalonneCondamine catchments) (Table 5).

\section{Discussion}

Isolation and subsequent genetic divergence can occur in populations of continuously aquatic freshwater species inhabiting separate drainages, because the terrestrial habitat can represent an insurmountable barrier, precluding dispersal and connectivity among drainages. Populations of $M$. australiense clustered into two main clades, corresponding geographically to the two major

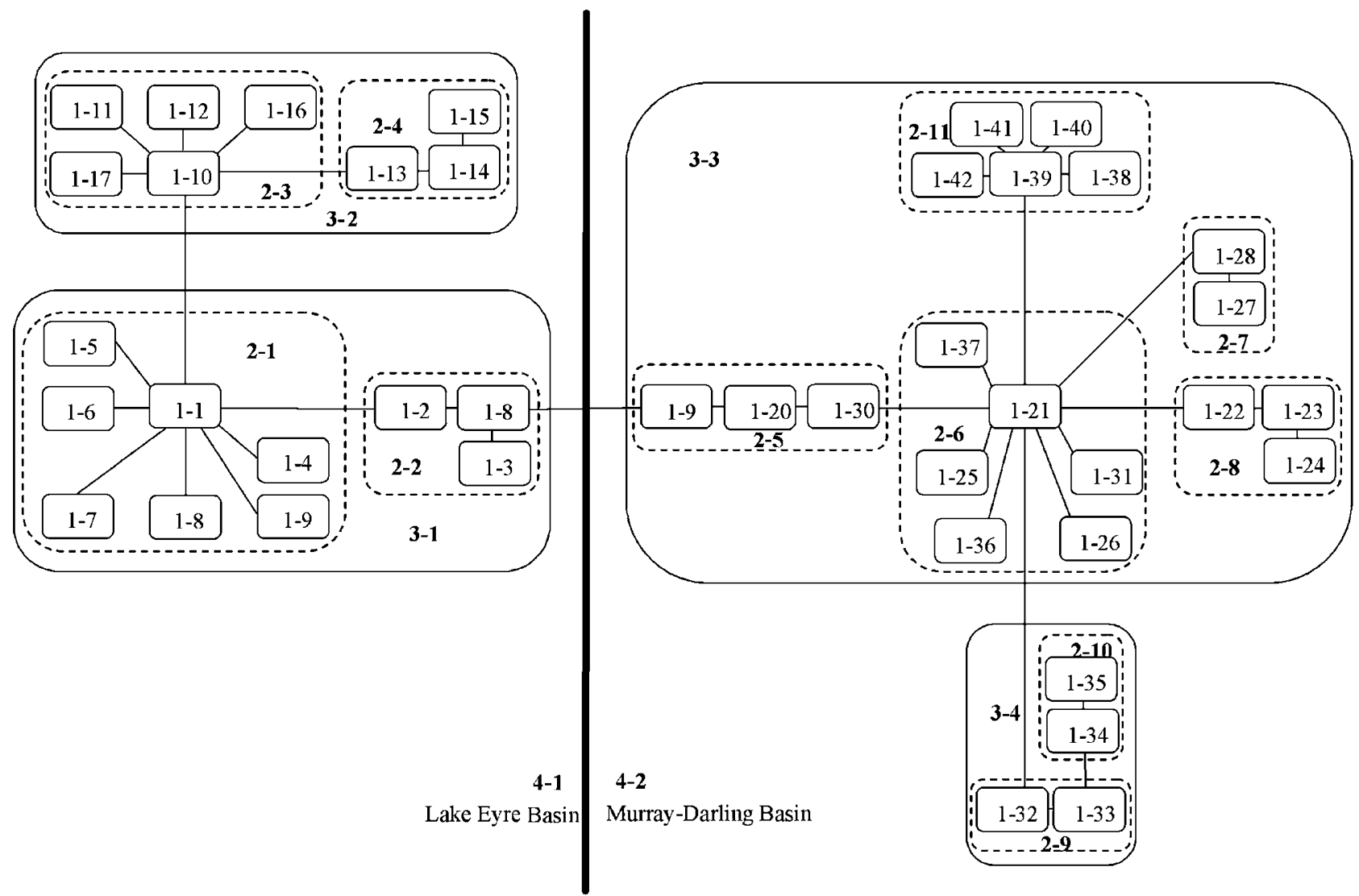

Figure 3 Two-, three- and four-step clade nesting for the hypothesised network with 95\% plausible set of haplotype connections. Clade step delineation is shown next to each nesting box. A solid branch between haplotype 1-98 is representative of a single base pair change in the mitochondrial sequence. 
Table 4 Nested clade analysis showing clade $\left(D_{C}\right)$, nested $\left(D_{N}\right)$ and interior-tip clade $(I-T)$ distances

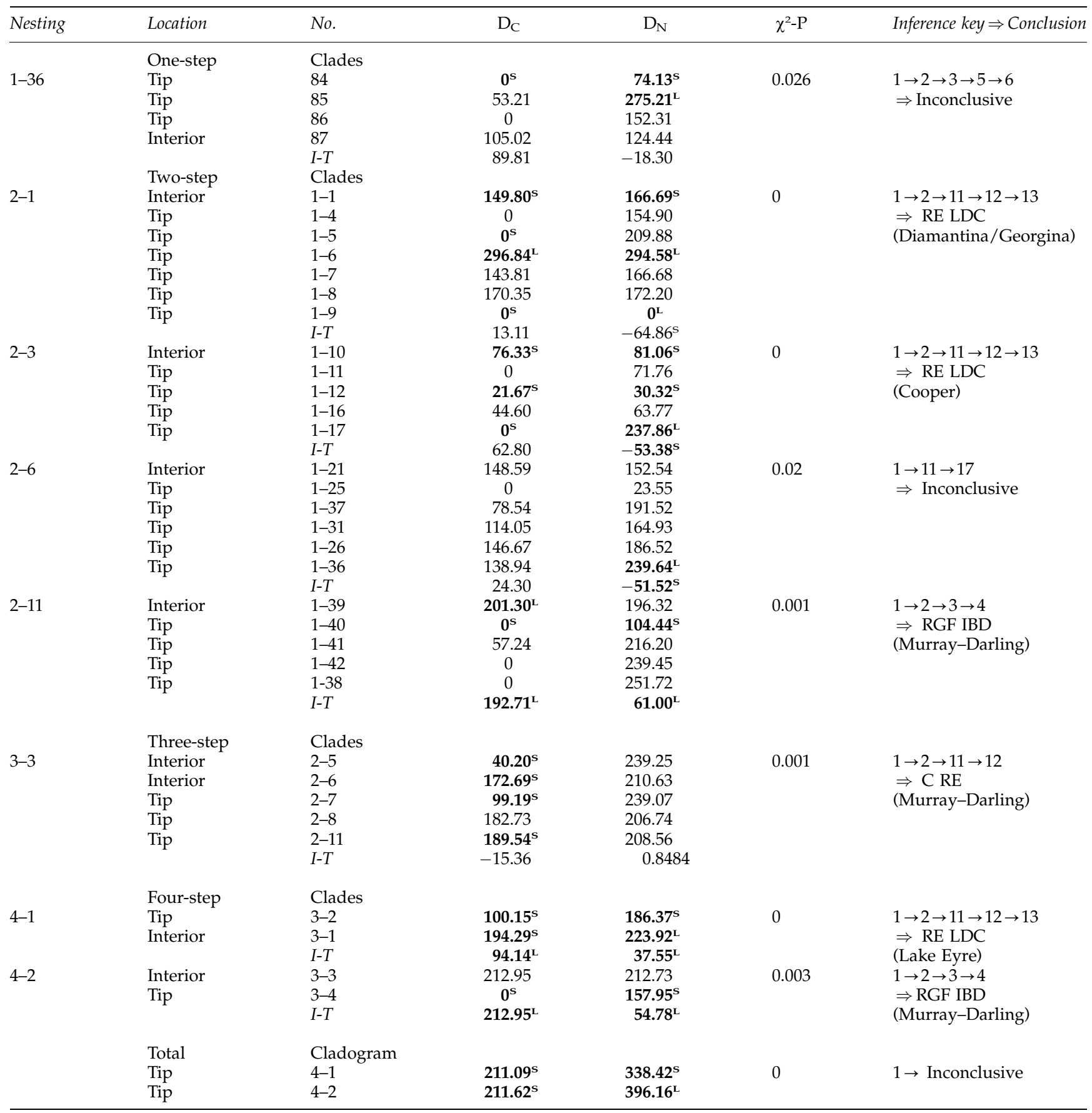

Only clades with significant permutational $\chi^{2}$ probabilities for geographic structure have been included in the table. Significantly small or large values for ' $D_{\mathrm{C}}$ ', ' $D_{\mathrm{N}}$ ' and ' $I-T^{\prime}$ ' are in bold and indicated by ' $\mathrm{S}$ ' and ' $\mathrm{L}$ ', respectively. 'Inference key $\Rightarrow$ Conclusion' refers to the update version of Inference Key (Templeton, 1998), whereby numbers indicate the steps and conclusions are abbreviated as follows: 'RE LDC', range expansion long-distance colonisation; 'RGF IBD' restricted gene flow with isolation by distance; 'C RE' contiguous range expansion.

drainage basins: the Lake Eyre and the Murray-Darling, which appeared to have diverged 800000 years ago. This major division between these drainages was also detected by Cook et al (2002) based on allozyme data. We suggest that gene flow has not occurred recently between the two basins, resulting in the high genetic divergence between the corresponding populations.

Furthermore, habitat fragmentation may reduce exchanges of individuals between adjacent populations, leading to an increase of differentiation through random drift. The Western Queensland region is a fragmented habitat for aquatic species. During dry periods, water becomes restricted to waterholes and rivers turn into dryland, resulting in a formidable system of barriers for freshwater fauna. It is only during occasional large floods that water fills up the channel system and provides the opportunity for aquatic dispersal to neighbouring waterholes (Knighton and Nanson, 1997). Our genetic data 


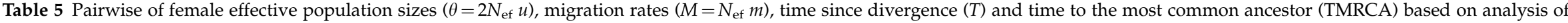
mtDNA COI using the MDIV program

\begin{tabular}{|c|c|c|c|c|c|c|c|}
\hline Balonne-Condamine & Border Rivers & Warrego & Paroo & Bulloo & Cooper & Diamantina & \\
\hline $\begin{array}{l}\text { Border rivers } \\
\theta=3.2 \\
M=12.55 \\
T=13000 \\
\text { TMRCA }=270000_{\mathrm{YBP}}\end{array}$ & - & & & & & & \\
\hline $\begin{array}{l}\text { Warrego } \\
\theta=2.3 \\
M=23.25 \\
T=38000 \\
\text { TMRCA }=788000 \mathrm{YBP}\end{array}$ & $\begin{array}{l}\theta=3.8 \\
M=19.4 \\
T=31600 \\
\text { TMRCA }=520000_{\mathrm{YBP}}\end{array}$ & - & & & & & \\
\hline $\begin{array}{l}\text { Paroo } \\
\theta=2.22 \\
M=2.02 \\
T=14800 \\
\text { TMRCA }=765000 \mathrm{YBP}\end{array}$ & $\begin{array}{l}\theta=5.03 \\
M=1.24 \\
T=83800 \\
\text { TMRCA }=436600_{\mathrm{YBP}}\end{array}$ & $\begin{array}{l}\theta=3.57 \\
M=2.9 \\
T=44600 \\
\text { TMRCA }=588000_{\mathrm{YBP}}\end{array}$ & - & & & & \\
\hline $\begin{array}{l}\text { Bulloo } \\
\theta=1.83 \\
M=0.01 \\
T=744000 \\
\text { TMRCA }=997000 \mathrm{YBP}\end{array}$ & $\begin{array}{l}\theta=4.18 \\
M=0.01 \\
T=724500 \\
\text { TMRCA }=901600 \mathrm{YBP}\end{array}$ & $\begin{array}{l}\theta=2.2 \\
M=0.1 \\
T=762600 \\
\text { TMRCA }=828300_{\mathrm{YBP}}\end{array}$ & $\begin{array}{l}\theta=3.54 \\
M=0.1 \\
T=501500 \\
\text { TMRCA }=670000_{\mathrm{YBP}}\end{array}$ & - & & & 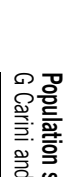 \\
\hline $\begin{array}{l}\text { Cooper } \\
\theta=2.77 \\
M=0.01 \\
T=812000 \\
\text { TMRCA }=867000_{\text {ҮВP }}\end{array}$ & $\begin{array}{l}\theta=4.73 \\
M=0.02 \\
T=780000 \\
\text { TMRCA }=721000_{\mathrm{YBP}}\end{array}$ & $\begin{array}{l}\theta=2.69 \\
M=0.12 \\
T=739000 \\
\text { TMRCA }=753000_{\mathrm{YBP}}\end{array}$ & $\begin{array}{l}\theta=3.85 \\
M=0.1 \\
T=436000 \\
\text { TMRCA }=633000_{\text {YBP }}\end{array}$ & $\begin{array}{l}\theta=2.59 \\
M=0.2 \\
T=203000 \\
\text { TMRCA }=293000_{\text {YBP }}\end{array}$ & - & & 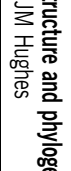 \\
\hline $\begin{array}{l}\text { Diamantina } \\
\theta=2.34 \\
M=0.01 \\
T=722000 \\
\text { TMRCA }=903000 \mathrm{YBP}\end{array}$ & $\begin{array}{l}\theta=4.61 \\
M=0.03 \\
T=814400 \\
\text { TMRCA }=863000_{\mathrm{YBP}}\end{array}$ & $\begin{array}{l}\theta=2.62 \\
M=0.1 \\
T=786000 \\
\text { TMRCA }=833000_{\mathrm{YBP}}\end{array}$ & $\begin{array}{l}\theta=3.46 \\
M=0.1 \\
T=473000 \\
\text { TMRCA }=633000_{\text {YBP }}\end{array}$ & $\begin{array}{l}\theta=2.28 \\
M=0.3 \\
T=157700 \\
\text { TMRCA }=273300_{\mathrm{YBP}}\end{array}$ & $\begin{array}{l}\theta=3 \\
M=0.2 \\
T=260000 \\
\text { TMRCA }=2700000_{\mathrm{YBP}}\end{array}$ & - & 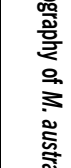 \\
\hline $\begin{array}{l}\text { Georgina } \\
\theta=1.64 \\
M=0.09 \\
T=1060000 \\
\text { TMRCA }=1110000_{\mathrm{YBP}}\end{array}$ & $\begin{array}{l}\theta=3.69 \\
M=0.01 \\
T=849000 \\
\text { TMRCA }=943000_{\mathrm{YBP}}\end{array}$ & $\begin{array}{l}\theta=2.1 \\
M=0.09 \\
T=1000000 \\
\text { TMRCA }=1090000_{\mathrm{YBP}}\end{array}$ & $\begin{array}{l}\theta=3.13 \\
M=0.1 \\
T=750000 \\
\text { TMRCA }=778000_{\text {YBP }}\end{array}$ & $\begin{array}{l}\theta=1.62 \\
M=0.3 \\
T=89100 \\
\text { TMRCA }=330000_{\mathrm{YBP}}\end{array}$ & $\begin{array}{l}\theta=2.33 \\
M=0.2 \\
T=221000 \\
\text { TMRCA }=303000_{\mathrm{YBP}}\end{array}$ & $\begin{array}{l}\theta=2.42 \\
M=0.4 \\
T=50400 \\
\text { TMRCA }=270000_{\mathrm{YBP}}\end{array}$ & 烝 \\
\hline
\end{tabular}


detected significant levels of genetic variation within and among catchments as well as a high number of haplotypes and unique clades at some sites (Wilson, Lake Eyre basin and Glencoe, Murray-Darling basin; Figure 1), indicating a general pattern of restricted gene flow.

We suggest that the main consequence of this mosaic of aquatic landscape in Western Queensland is the subdivision of $M$. australiense into many arrays of localised populations and that, despite the potential for movement of individuals across catchment boundaries at flood times, almost none occurs. Our interpretation of this genetic subdivision implies that: (a) despite the potential for long-distance dispersal of some aquatic species, the episodic floods do not ensure a good network of connectivity among waterholes and/or (b) during floods the freshwater prawns do not maximise their potential for dispersal and tend to remain in the waterhole of origin. Even if in a completely different type of stream environment, there is some evidence that, during floods, freshwater fauna accumulate into refugial areas of low hydraulic disturbance, thus avoiding dispersal (Winterbottom et al, 1997).

During the Pleistocene, periods of high increased rainfall alternated with periods of very dry weather, associated with interglacial and glacial phases, respectively (Kershaw and Nanson, 1993; Alley, 1998). These climate oscillations deeply changed the hydrological flood regimes in Western Queensland, modifying levels of connectivity between populations of aquatic species. We propose that extensive floods and temporary internal lakes resulted in high levels of connectivity between waterholes during interglacial phases, promoting movement of freshwater prawns within but not between the major drainage basins, resulting in a series of population range expansions.

The late Pleistocene signalled the gradual stabilisation of the climate towards the contemporary quasi-periodic arid hydrological regime of Western Queensland (Alley, 1998). It is likely that the reduction in intensity and frequency of the floods as well as ongoing aridity progressively isolated populations, first from different catchments and then even within catchments.

It was estimated that populations of $M$. australiense in different catchments of the Lake Eyre basin became separated much earlier (260000-50000 years ago) than populations of the Murray-Darling basin (80000-13000 years ago). We suggest that, despite the progressive reduction of rainfall, floods were still able to connect catchments within the Murray-Darling basin until the end of the Pleistocene, due to the combined effect of geographic distance and hydrology patterns. The channels of the Murray-Darling are organised in a dendritic structure, whereby smaller tributary systems feed into increasingly fewer but longer channels (Williams, 1980; Young, 1999). These channels are less ephemeral than those in the Lake Eyre basin, therefore increasing the potential for connectivity between them. Our data also suggest that $M$. australiense colonised the Bulloo and the Cooper from the Georgina/Diamantina, possibly during the Pleistocene. The structure of the haplotype network indicated that the Cooper clade was derived from the Georgina/Diamantina clade, which is internal within the network and connected to the Murray-Darling group. Similarly, all the haplotypes of the Bulloo cluster with the Georgina/ Diamantina clade.

In both historical biogeography and comparative phylogeography (Avise, 2000), the most parsimonious explanation for multiple taxonomic groups to exhibit common spatial patterns of evolutionary subdivision is that they have been subjected to the same environmental history. For example, a general pattern of restricted gene flow was detected in a number of species in Western Queensland (Hughes et al, in review; Hughes and Hillyer, 2003; Carini and Hughes, in review), suggesting that levels of movements of individuals were limited among populations despite potential mechanisms of dispersal of the species. The Wilson site (Cooper catchment, Lake Eyre basin) contained a unique clade for $M$. australiense. Similarly, this pattern was observed for a mussel species (Hughes et al, in review), indicating that a geographic barrier has isolated this site for long enough to allow the local populations of prawns and mussels to evolve a unique set of haplotypes, despite their potential dispersal capabilities.

The phylogenetic break between populations of $M$. australiense of the Lake Eyre and the Murray-Darling basins has also been identified for a mussel species, Velesunio ambiguus (Hughes et al, in review), a crayfish, Cherax destructor (Hughes and Hillyer, 2003), and a freshwater snail, Notopala sublineata (Carini and Hughes, in review). Such congruence between intraspecific phylogeography from different co-distributed species suggests that these communities have undergone substantial periods of independent evolution due to the same vicariant event (Avise, 1992), in this case the historical geographic separation of the two drainages. Also, evidence for some levels of historical gene flow across catchment boundaries has been detected for a number of species (Hughes et al, in review; Hughes and Hillyer, 2003; Carini and Hughes, in review), including M. australiense. In all these cases, it has been suggested by the authors that the climate oscillations of the Pleistocene have caused changes in levels of connectivity between species, resulting in population range expansions. Although preliminary, these observations could indicate that aquatic species inhabiting Western Queensland rivers could share a common biogeographic history.

In conclusion, this study indicated that episodic dispersal of $M$. australiense across catchment boundaries was possible during the Pleistocene, but that contemporary movements of individuals are restricted both between and within catchments. Therefore, despite the potential dispersal capabilities of the species, the population of $M$. australiense is fragmented throughout Western Queensland and gene flow is limited among populations.

The outcomes of this study are particularly important when taken in conjunction with the findings from studies of other aquatic species of the region (Hughes and Hillyer, 2003; Carini and Hughes, in review; Hughes et al, in review).

It has been suggested that comparative analysis of phylogeographies for co-distributed species can not only provide insights into the biogeographical history of a region (Avise, 1992; Riddle, 1996), but also extends the use of intraspecific phylogeography to identify evolutionary significant assemblages of species (Avise, 1992; Moritz, 1995). The implications of restricted gene flow 
and population fragmentation reported here for $M$. australiense and for other freshwater invertebrates by Hughes and Hillyer (2003), Carini and Hughes (in review) and Hughes et al (in review) may affect the long-term survival of these species. We suggest that, if local populations go extinct as a result of modification of their suitable habitat, the chances of recolonisation would be low. The natural habitat for the freshwater fauna of Western Queensland has recently been modified by heavy human impact (eg excessive extraction of water for irrigation, and introduction of alien species such as the carp, Cyprinus carpio; Sheldon, personal comment). Some species, such as N. sublineata, once widespread, have already apparently disappeared in the MurrayDarling system and are in decline in other areas (Walker, 1996). It has been proposed that comparative analyses of phylogeographies provide a way to investigate geographical patterns of the genetic component of biodiversity as one element of assessing priorities for conservation planning (Avise, 1992; Moritz, 1995). Understanding and combining all the information for freshwater organisms of Western Queensland is essential to develop a suitable management plan for the preservation of such a pristine environment and its endemic fauna.

\section{Acknowledgements}

This work was made possible by the financial support of Griffith University and the Cooperative Research Centre for Freshwater Ecology. We thank all the farmers who gave permission to collect samples from waterholes on their property in the Cooper, Diamantina and Georgina catchments and all the assistants with the fieldwork, particularly Ben Cook and Kate Durrant. We thank Andrew Baker and Tim Page for their critical reading of the manuscript and Stuart Bunn for helpful discussions about the species and the study sites. All the sampling was performed under a Scientific Purpose Permit (No. WITK 00463902) issued by Queensland Parks and Wildlife Service.

\section{References}

Alley NA (1998). Cainozoic stratigraphy, palaeoenvironments and geological evolution of the Lake Eyre Basin. Palaeogeogr Palaeoclimatol Palaeoecol 144: 239-263.

Avise J (1992). Molecular population structure and the biogeographic history of a regional fauna: a case history with lessons for conservation biology. Oikos 63: 62-76.

Avise J (2000). Philogeography. The History and Formation of Species, Harvard University Press: Cambridge, MA, USA.

Birky CWJ, Fuerst P, Maruyama T (1989). Organelle gene diversity under migration, mutation, and drift: equilibrium expectations, approach to equilibrium, effects of heteroplasmic cells, and comparison to nuclear genes. Genetics 121: 613-627.

Carini G, Hughes JM (in review). Population structure of Notopala sublineata (Gastropoda: Viviparidae) in Western Queensland: evidence for some ancient long distance colonisation.

Clement M, Posada D, Crandall KA (2000). TCS: a computer program to estimate gene genealogies. Mol Ecol 9: 1657-1659.

Cook BD, Bunn SE, Hughes JM (2002). Genetic structure and dispersal of Macrobrachium australiense (Decapoda: Palaemonidae) in western Queensland, Australia. Freshwater Biol 47: 2098-2112.
Excoffier L, Smouse P, Quattro J (1992). Analysis of molecular variance inferred from metric distances among haplotypes: application to human mitochondrial DNA restriction data. Genetics 131: 479-491.

Folmer O, Black M, Hoeh W, Lutz R, Vrijenhoek R (1994). DNA primers for amplification of mitochondrial cytochrome $c$ oxidase subunit I from diverse metazoan invertebrates. Mol Marine Biol Biotechnol 3: 294-299.

Gibling MR, Nanson GC, Maroulis JC (1998). Anastomosing rivers sedimentation in the Channel Country of central Australia. Sedimentology 45: 595-619.

Hughes JM, Baker A, Bartlett C, Bunn S, Goudkamp K, Somerville J (in review). Past and present patterns of connectivity among populations of four cryptic species of freshwater mussels Velesunio sp. in central Australia. Molecular Ecology.

Hughes JM, Bunn SE, Hurwood DA, Cleary C (1998). Dispersal and recruitment of Tasiagma ciliata (Trichoptera: Tasmiidae). In rainforest streams, southeast Queensland, Australia. Freshwater Biol 41: 1-10.

Hughes JM, Hillyer M (2003). Pattern of connectivity among populations of Cherax destructor (Decapoda: Parastacidae) in Western Queensland, Australia. J Marine Freshwater Res 54: $1-10$.

Hurwood DA, Hughes JM (2001). Nested Clade analysis of the freshwater shrimp, Caridina zebra (Decapoda: Atyidae), from north-eastern Australia. Mol Ecol 10: 113-125.

Kershaw AP, Nanson GC (1993). The last full glacial cycle in the Australian region. Global Planet Change 7: 1-9.

Knighton D, Nanson G (1994). Flow transmission along and arid zone anastomosing rivers, Cooper Creek, Australia. Hydrol Processes 8: 137-154.

Knighton D, Nanson G (1997). Distinctiveness, diversity and uniqueness in arid zone river systems. In: Thomas DSG (ed) Arid Zone Geomorphology Process, Form and Change in Drylands, 2nd edn. Wiley and Sons: Chinester.

Lee CL, Fielder DR (1983). Agonistic behaviour and development of dominance hierarchies in the freshwater prawn, Macrobrachium australiense Holthuis, 1950 (Crustacea: Palaemonidae). Behaviour 83: 1-17.

Lee CL, Fielder DR (1984). Swimming response to water current stimulus in the freshwater prawn, Macrobrachium australiense Holthuis, 1950. Crustaceana 46: 249-256.

McGlashan DJ, Hughes JM (2001). Low levels of mitochondrial DNA and allozyme variation among populations of freshwater fish Hypseleotris compressa (Gobiidae: Eleotridinae): implications for its biology, populations connectivity and history. Heredity 86: 222-233.

Miller MP, Blinn DW, Keim P (2002). Correlations between observed dispersal capabilities and patterns of genetic differentiation in populations of four aquatic insect species from the Arizona White Mountains, U.S.A. Freshwater Biol 47: 1660-1673.

Moritz C (1995). Uses of molecular phylogenies for conservation. Philos Trans Royal Soc B349: 113-118.

Nielsen R (2002) MDIV software. Available at http://serloopp.tc.cornell.edu/cbsu/mdiv.htm

Nielsen R, Wakeley JW (2001). Distinguishing migration from isolation: an MCMC approach. Genetics 158: 885-896.

Posada D, Crandell KA, Templeton AR (2000). GeoDis: a program for the cladistic analysis of the geographical distribution of genetic haplotypes. Mol Ecol 9: 487-488.

Riddle BR (1996). The molecular phylogeography bridge between deep and shallow history in continental biotas. Trends in Ecol Evol 11: 207-211.

Schneider S, Roessli D, Excoffier L (2000). ARLEQUIN, Version 2.00: Software for Population Genetics and Population Analysis, Genetics and Biometry Laboratory, University of Geneva: Geneva.

Shank TM, Black MB, Halanych KM, Lutz RA, Vrijenhoek RC (1999). Miocene radiation of deep-sea hydrothermal vent 
shrimp (Caridea: Bresiliidae): evidence from mitochondrial cytochrome oxidase subunit I. Mol Phylogenet Evol 13: 244-254.

Sheldon F, Walker KW (1998). Spatial distribution of littoral invertebrates in the lower Murray-Darling River system, Australia. Marine Freshwater Res 49: 171-182.

Slatkin M (1987). Gene flow and geographic structure of natural populations. Science 236: 787-792.

Tajima F (1989). Statistical method for testing the neutral mutation hypothesis by DNA polymorphism. Genetics 123: 585-595.

Tamura K, Aotsuka T (1988). Rapid isolation method of animal mitochondrial DNA by the alkaline lysis procedure. Biochem Genet 26: 815-819.

Templeton AR (1998). Nested clade analysis of phylogeographic data: testing hypotheses about gene flow and population history. Mol Ecol 7: 381-397.

Templeton AR, Crandall KA, Sing CF (1992). A cladistic analysis of phenotypic associations with haplotypes inferred from restriction endonuclease mapping and DNA sequence data. III. Cladogram estimation. Genetics 132: 619-633.
Templeton AR, Routman E, Phillips CA (1995). Separating population structure from population history: a cladistic analysis of the geographical distribution of mitochondrial DNA haplotypes in the Tiger Salamander, Ambystoma tigrinum. Genetics 140: 767-782.

Walker KF (1996). The river snail Notopala hanleyi: an endangered pest. Xanthopus (Nat Conserv Soc SA) March: 1-5.

Williams WD (1980). Australian Freshwater Life, Macmillan Publishing: Melbourne.

Winterbottom JH, Orton SE, Hildrew AG, Lancaster J (1997). Field experiments on flow refugia in streams. Freshwater Biol 37: 569-580.

Young WJ (1999). Hydrologic descriptions of semi-arid rivers: an ecological perspective. In: Kingsford RT (ed) A Freeflowing River: The Ecology of the Paroo River, National Parks and Wildlife Service: Hurstville. pp 77-96.

\section{Appendix 1}

A total of 76 variable sites for 98 haplotypes of COI fragment from $402 \mathrm{M}$. australiense specimens are shown in Table A1.

\section{Table A1}

\begin{tabular}{|c|c|c|c|c|c|c|c|c|}
\hline [ & & 111111111 & 1111122222 & 2222222233 & 3333333333 & 3333333444 & 444444 & \\
\hline [ & 1122235566 & 7111233555 & 6788913344 & 6667779900 & 0112334466 & 6788999000 & 0123444456 & 788 \\
\hline & 5814544737 & 8147928069 & 5213263736 & 1470391706 & 9281692503 & 6526039235 & 8763145702 & $426254]$ \\
\hline $\mathrm{H}-1$ & АCGTCTCAАT & СТСССТТАТА & CCCAAGTAGT & ATCAGAACCG & ССТАAТСССG & AGCCTAGCCA & АСАААСТТАA & ATGACC \\
\hline $\mathrm{H}-3$ & $\ldots \ldots \ldots$ & $\ldots \ldots \ldots$ & $\ldots \ldots \ldots$ & $\ldots \ldots A$ & $\ldots \ldots \ldots$ & $\ldots \ldots \ldots$ & $\ldots$ C..... & $\ldots \ldots$ \\
\hline $\mathrm{H}-4$ & $\ldots \ldots \ldots$ & $\ldots \ldots \ldots$ & $\cdots \cdots \cdots$ & $\cdots \cdots \cdots$ & $\ldots \ldots$ & $\ldots \mathrm{T} \ldots \ldots$ & $\ldots \mathrm{C} \ldots \ldots$ & $\ldots \ldots$ \\
\hline $\mathrm{H}-5$ & $\ldots \ldots$ & $\mathrm{T} \ldots \ldots$ & $\cdots \cdots \cdots$ & $\cdots \cdots \cdots$ & $\cdots \cdots \cdots$ & $\ldots \ldots \ldots$ & $\ldots \mathrm{C} \ldots \ldots$ & $\ldots \ldots$ \\
\hline $\mathrm{H}-6$ & $\ldots \ldots$ & T. T..... & $\ldots \ldots$ & $\ldots \ldots$ & $\ldots \ldots$ & $\ldots \ldots$ & $\ldots \mathrm{C} \ldots \ldots$ & $\ldots \ldots$ \\
\hline $\mathrm{H}-7$ & $\ldots \ldots$ & $\ldots \mathrm{T} \ldots \ldots$ & $\ldots \ldots$ & $\ldots \ldots$ & $\ldots \ldots$ & $\ldots \ldots$ & $\ldots \mathrm{C} \ldots \ldots$ & $\ldots \ldots$ \\
\hline $\mathrm{H}-8$ & $\ldots \ldots \ldots$ & $\ldots \ldots \ldots$ & $\ldots$ G.... & $\ldots \ldots \ldots$ & $\ldots \ldots \ldots$ & $\ldots \ldots \ldots$ & $\ldots \mathrm{C} \ldots \ldots$ & $\ldots \ldots$ \\
\hline $\mathrm{H}-2$ & $\ldots \ldots \ldots$ & $\ldots \ldots \ldots$ & $\ldots \ldots \ldots$ & $\ldots \ldots \ldots$ & $\ldots \ldots$ & $\ldots \ldots \ldots$ & $\ldots \mathrm{C} \ldots \ldots$ & $\ldots \ldots$ \\
\hline $\mathrm{H}-9$ & $\ldots \ldots$ & $\ldots \ldots \ldots$ & $\ldots \ldots$ & $\ldots \ldots \ldots$ & A........ & $\ldots \ldots \ldots$ & $\ldots \ldots$ & $\ldots \ldots$ \\
\hline $\mathrm{H}-10$ & $\ldots \ldots$ & $\ldots \ldots c$ & $\ldots \ldots$ & $\ldots \ldots \ldots$ & $\ldots \ldots$ & $\ldots \ldots$ & $\ldots \mathrm{C} \ldots \ldots$ & $\ldots \ldots$ \\
\hline $\mathrm{H}-11$ & $\ldots \ldots$ & $\ldots \ldots \ldots$ & $\ldots \ldots$ & $\ldots \ldots \ldots$ & $\ldots \ldots$ & $\ldots \mathrm{T} \ldots \ldots$ & $\ldots \ldots$ & $\ldots \ldots$ \\
\hline $\mathrm{H}-12$ & $\ldots \ldots$ & $\ldots \ldots$ & $\ldots \ldots$ & $\ldots \ldots \ldots$ & $\ldots \ldots$ & $\ldots \ldots$ & .. G... & $\ldots \ldots$ \\
\hline $\mathrm{H}-13$ & $\ldots \mathrm{T} \ldots$ & $\ldots \ldots \mathrm{G}$ & $\ldots \ldots$ & $\ldots \ldots$ & $\ldots \ldots$ & $\ldots \ldots$ & . G G.. & $\ldots \ldots$ \\
\hline $\mathrm{H}-14$ & $\ldots \ldots$ & $\ldots \ldots \mathrm{G}$ & $\ldots \ldots$ & $\ldots \ldots$ & $\ldots \ldots$ & $\ldots \ldots$ & $\ldots \mathrm{C} \ldots \ldots$ & $\ldots \ldots$ \\
\hline $\mathrm{H}-15$ & $\ldots \ldots \ldots$ & C...... & $\mathrm{T} \ldots \ldots$ & $\ldots \ldots \ldots$ & $\ldots \ldots \ldots$ & $\ldots \ldots$ & $\ldots$ C..... & $\ldots \ldots$ \\
\hline $\mathrm{H}-16$ & $\ldots \ldots$ & $\ldots \ldots$ & $\mathrm{T} \ldots \ldots$ & $\ldots \ldots$ & $\ldots \ldots \ldots$ & $\ldots \ldots \ldots$ & $\ldots$ C...... & $\cdots \cdots$ \\
\hline $\mathrm{H}-17$ & $\cdots \cdots$ & $\ldots \ldots$ & $\mathrm{T} \ldots \ldots$ & $\ldots \ldots$ & $\cdots \cdots$ & $\ldots \ldots \mathrm{T}$ & $\ldots \mathrm{C} \ldots \ldots$ & $\ldots \ldots$ \\
\hline $\mathrm{H}-18$ & $\ldots \ldots$ & $\ldots \ldots$ & $\ldots \ldots$ & $\ldots$ A. . . & $\cdots \cdots$ & $\ldots \ldots \mathrm{T}$ & $\ldots \mathrm{C} \ldots \ldots$ & $\cdots \cdots$ \\
\hline $\mathrm{H}-19$ & $\ldots \ldots$ & $\cdots \cdots \cdots$ & $\cdots \cdots$ & $\cdots \cdots$ & $\cdots \cdots$ & $\ldots \ldots \mathrm{T}$ & $\cdots \cdots$ & $\ldots \ldots$ \\
\hline $\mathrm{H}-2 \mathrm{O}$ & $\ldots \ldots$ & $\ldots \ldots$ & $\ldots \ldots$ & $\ldots \ldots$ & $\ldots . .$. & $\ldots \ldots \mathrm{T}$ & $\cdots$ & $\ldots \ldots$ \\
\hline $\mathrm{H}-21$ & $\ldots \ldots$ & $\ldots \ldots$ & $\ldots \ldots$ & $\ldots \ldots$ & $\ldots \ldots$ & $\ldots \mathrm{C} \ldots \mathrm{T}$ & $\cdots$ & $\cdots \cdots$ \\
\hline $\mathrm{H}-22$ & $\ldots \ldots \ldots$ & $\ldots \ldots \ldots$ & $\ldots$. A... & $\ldots \ldots \ldots$ & $\ldots \ldots \ldots$ & $\ldots \ldots \mathrm{T}$ & $\ldots \ldots$ & $\ldots \ldots$ \\
\hline $\mathrm{H}-23$ & $\ldots \ldots \ldots$ & $\ldots$.... & $\ldots \ldots$ & $\ldots \ldots \ldots$ & $\ldots \ldots \ldots$ & $\ldots \ldots \mathrm{T}$ & $\ldots \ldots$ & $\ldots \ldots$ \\
\hline $\mathrm{H}-24$ & $\ldots \ldots$ & 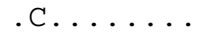 & $\ldots \ldots A$ & $\ldots \ldots \ldots$ & $\ldots \ldots$ & $\ldots \ldots$ & $\ldots$ & $\ldots \ldots$ \\
\hline $\mathrm{H}-25$ & $\ldots \ldots \ldots$ & $\ldots \ldots$ & $\ldots \ldots A$ & $\ldots \ldots \ldots$ & $\ldots \ldots$ & $\ldots \ldots \ldots$ & $\ldots \mathrm{C} \ldots \ldots$ & $\ldots \ldots$ \\
\hline $\mathrm{H}-26$ & $\ldots \ldots$ & $\ldots \ldots$ & $\ldots \ldots$ & $\ldots \ldots$ & $\ldots$ C..... & $\ldots \ldots \ldots$ & $\ldots$ C..... & $\ldots \ldots$ \\
\hline $\mathrm{H}-27$ & $\mathrm{~T} \ldots \ldots$ & & $\ldots \ldots$ & $\ldots \ldots$ & $\ldots \mathrm{C} \ldots \ldots$ & & $\ldots \mathrm{C} \ldots \mathrm{G}$. & $\ldots \ldots$ \\
\hline $\mathrm{H}-28$ & T........ & $\ldots \ldots$ & $\cdots \cdots$ & $\cdots \cdots \cdots$ & . G . . . . & $\ldots$. G... & $\ldots \mathrm{C} \ldots \ldots$ & G.... \\
\hline $\mathrm{H}-29$ & $\mathrm{~T} \ldots \ldots$ & & $\ldots \ldots$ & $\ldots \ldots$ & . G. . . . & $\ldots$. G... & $\ldots \mathrm{C} \ldots \ldots$ & $\ldots \ldots$ \\
\hline $\mathrm{H}-3 \mathrm{O}$ & T...A. & & $\mathrm{T} \ldots \ldots$ & & . G..... & $\ldots$. G... & $\ldots \mathrm{C} \ldots \ldots$ & $\ldots \ldots$ \\
\hline $\mathrm{H}-31$ & $\mathrm{~T} \ldots \ldots$ & & & & . G..... & $\cdots \cdots \cdots$ & $\ldots \mathrm{C} \ldots \ldots$ & $\ldots \ldots$ \\
\hline $\mathrm{H}-32$ & $\mathrm{~T} \ldots \ldots$ & $\ldots \ldots \ldots$ & $\ldots \ldots$ & & . G..... & $\ldots$... & $\ldots \mathrm{C} \ldots \ldots$ & $\ldots \ldots$ \\
\hline $\mathrm{H}-33$ & $\mathrm{~T} \ldots \ldots$ & $\cdots \cdots \cdots$ & $\cdots \cdots \cdots$ & $\cdots \cdots \cdots$ & $\cdots \cdots \cdots$ & $\ldots$. G... & $\ldots$ C.... & $\cdots \cdots$ \\
\hline $\mathrm{H}-34$ & $\ldots \ldots$ & $\ldots \ldots$ & & & $\ldots \ldots$ & $\ldots$. . . . & $\ldots \mathrm{C} \ldots \ldots$ & $\ldots \ldots$ \\
\hline $\mathrm{H}-35$ & 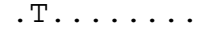 & $\cdots \cdots \cdots$ & $\cdots \cdots \cdots$ & $\cdots$ A. . & $\cdots \cdots \cdots$ & $\cdots \cdots \cdots$ & $\ldots$ C.... & $\cdots \cdots$ \\
\hline $\mathrm{H}-36$ & . T. T.... & $\ldots \ldots$ & $\ldots \ldots$ & $\ldots \ldots$ & $\ldots \ldots$ & $\ldots \ldots$ & $\ldots \mathrm{C} \ldots \ldots$ & $\cdots \cdots$ \\
\hline
\end{tabular}




\begin{tabular}{|c|c|c|c|c|c|c|c|c|}
\hline & $\ldots \ldots \ldots$ & & & & & $\ldots$ & . $\ldots \ldots$ & \\
\hline+-38 & $\mathrm{~T} \ldots . .$. & $\ldots \ldots$ & & $\ldots \ldots \ldots$ & $\ldots \ldots \ldots$ & $\ldots \ldots \ldots$ & $\ldots$ C...... & . G.. \\
\hline-39 & $\mathrm{~T} \ldots \ldots$ & $\cdots \cdots \cdots$ & $\cdots \cdots$ & $\cdots \cdots \cdots$ & $\ldots \ldots \ldots$ & $\ldots \ldots \ldots$ & $\ldots$ C..... & \\
\hline-40 & 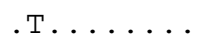 & $\ldots \ldots \ldots$ & $\ldots \ldots$ & $\ldots \ldots \ldots$ & $\ldots$ C..... & $\ldots \ldots \ldots$ & $\ldots$ C..... & . G... \\
\hline & $\ldots \ldots$ & $\ldots \ldots \ldots$ & $\ldots \ldots \ldots$ & $\ldots \ldots \ldots$ & $\ldots \ldots \ldots$ & $\ldots \ldots \ldots G$ & $\ldots$ C..... & \\
\hline $\mathrm{H}-42$ & $\ldots \ldots$ & $\ldots \ldots \ldots$ & $\ldots \ldots \ldots$ & $\ldots$. G... & $\ldots \ldots \ldots$ & $\ldots \ldots \ldots$ & $\ldots$ C.... & .G... \\
\hline $1-43$ & T..... & $\ldots \ldots \ldots$ & $\ldots \ldots \ldots$ & $\ldots$. G.... & $\ldots \ldots \ldots$ & $\ldots \ldots \ldots$ & $\ldots$ C.... & $\ldots \ldots$ \\
\hline-44 &. TA....... & $\ldots \ldots \ldots$ & $\ldots \ldots \ldots$ & $\ldots$. G... & $\ldots \ldots \ldots$ & $\ldots \ldots$ & $\ldots$ C..... & \\
\hline & $\ldots \ldots$ & $\ldots \ldots \ldots$ & $\ldots \ldots \ldots$ & $\ldots \ldots \ldots$ & $\ldots \ldots \ldots$ & $\ldots \ldots \ldots$ & $\ldots$ C.... & G... \\
\hline-46 & T...... & $\ldots \ldots$.... & $\ldots \ldots \ldots$ & $\ldots \ldots \ldots$ & $\ldots \ldots \ldots$ & $\ldots \ldots \ldots$ & $\ldots$ C..... & $\ldots \ldots$ \\
\hline-47 & $\mathrm{~T} \ldots \ldots$ & $\ldots \ldots \ldots$ & $\ldots \ldots \ldots$ & $\ldots \ldots \ldots$ & $\ldots \ldots \ldots$ & $\ldots \ldots \ldots$ & $\ldots$ C.... & $\ldots \mathrm{T}$ \\
\hline-48 & $\ldots \ldots$ & $\ldots \ldots \ldots$ & & C....... & $\ldots \ldots \ldots$ & $\ldots \ldots$ & $\ldots$ C.. & \\
\hline & $\ldots \ldots$ & $\ldots \ldots \ldots$ & T...... & $\ldots \ldots \ldots$ & $\ldots \ldots \ldots$ & $\ldots \ldots$ & . C.. & \\
\hline & T..... & $\ldots$ Т.... & $\ldots \ldots \ldots$ & $\ldots$. . G . & $\ldots \ldots \ldots$ & $\ldots \ldots \ldots$ & $\ldots$ C.... & \\
\hline-51 & $\cdots \cdots$ & $\ldots \ldots \ldots$ & $\ldots \ldots \ldots$ & $\ldots \ldots \ldots$ & $\ldots \ldots \ldots$ & $\ldots \ldots$ A. & $\ldots$ C.... & $\ldots$ \\
\hline-52 & & & & & $\ldots \ldots \mathrm{T} \cdot \mathrm{A}$ & & . C. . & \\
\hline 53 & $\ldots \ldots G$ & & $\ldots \mathrm{G} \ldots \mathrm{CC}$ & $\cdots G A$ & $\ldots$ C.... & $\ldots \ldots A$ & $\ldots$ C...C. & …… \\
\hline 54 & $\ldots$ C...G. & $\ldots \ldots \ldots$ & $\ldots \mathrm{G} \ldots \mathrm{CC}$ & $\ldots A \ldots$ & $\ldots \ldots \mathrm{CT} \ldots$ & $\ldots \ldots$ & . C...C. & $\ldots$ A... \\
\hline 55 & $\ldots \ldots$ & $\ldots \ldots \ldots$ & $\ldots \mathrm{G} \ldots \mathrm{C}$ & $\ldots$ A. . . & $\ldots$ C...... & $\ldots \ldots$ & $\ldots$ C...C. & A. . . \\
\hline 56 & $\ldots \ldots$ & $\cdots \cdots \cdots \cdots$ & $\ldots \mathrm{G} \ldots \mathrm{CC}$ & $\ldots$ A.... & $\ldots$ C..... & $\ldots \ldots$ & $\ldots$ C...C. & .A... \\
\hline & $\ldots \ldots$ & $\ldots \ldots$. . . & $\ldots G \ldots C$ & $\ldots A \ldots$ & $\ldots$ C.... & $\ldots \ldots$ & $\ldots$ C...C. & A. . T \\
\hline 58 & $\ldots \mathrm{G}$. & $\ldots . .$. G. & $\ldots \mathrm{G} \ldots \mathrm{C}$ & $\ldots$. . . . & $\ldots$ C..... & $\ldots \ldots$ & $\ldots$ CC . . C . & A. . \\
\hline 59 & $\ldots G$ G. & $\ldots \ldots$. . . & $\ldots \mathrm{G} \ldots \mathrm{CC}$ & $\ldots A \ldots$ & $\ldots$ C..... & $\ldots \ldots$ & $\ldots$ C...C. & $\ldots A$ \\
\hline 60 & $\ldots \mathrm{C} \ldots \mathrm{G}$ & $\ldots . . . G$. & $\ldots \mathrm{G} \ldots \mathrm{CC}$ & $\ldots$ A.... & TC...... & $\ldots \ldots A$ & $\ldots$ C...C. & .A. \\
\hline & $\ldots \mathrm{C} \ldots \ldots$ & $\ldots \ldots$. . G. & $\ldots G \ldots$. C & $\ldots A \ldots$ & $\ldots$ C.... & $\ldots \ldots$ & $\ldots$ C...C. & \\
\hline-62 & $\ldots C \ldots G$ & $\ldots \ldots \ldots$ & $\ldots G \ldots A . C$ & G..A.... & $\ldots$ C.... & $\ldots \ldots$ & $\ldots$ C...C. & \\
\hline-63 & . T.C...G. & $\ldots \ldots \ldots \ldots$ & $\ldots \mathrm{G} \ldots \mathrm{CC}$ & G..A.... & $\ldots$ C.... & $\ldots \ldots$ & $\ldots$ C...C. & A... \\
\hline-64 & $\ldots \mathrm{C} \ldots \mathrm{G}$ & & ...G.A..CC & $\ldots$.... & $\ldots$ С... & $\ldots \ldots z$ & . CC . . C. & $\ldots A$ \\
\hline & $\ldots C \ldots G$. & $\ldots \ldots \ldots$ & $\ldots G$ & $\ldots A \ldots$ & . С... . & $\ldots \ldots$ & $\ldots$ CC ... C. & A. \\
\hline-66 & $\ldots \mathrm{G}$. & $\ldots \ldots \ldots$ & $\ldots G \ldots$. & $\ldots$ A.... & . С... Т. & $\ldots$ & $\ldots \mathrm{C}$ & A. . \\
\hline 67 & $\ldots \mathrm{C} \ldots \mathrm{G}$. & $\ldots . .$. & $\ldots \mathrm{TG} \ldots \mathrm{C}$ & $\ldots$ A.... & $\ldots$ C..... & $\ldots$ & . TCC. & .A. . \\
\hline 68 & $\ldots$ C...G. & $\cdots \cdots \cdots$ & $\ldots \mathrm{G} \ldots \mathrm{CC}$ & $\cdots$ A.... & $\ldots$ C..... & $\ldots A . F$ & $\ldots$ CC . . C . & $\ldots$ A. \\
\hline & $\ldots G$. & $\ldots \ldots \ldots \ldots$ & $\ldots G \ldots$ & $\ldots$ A.... & $\ldots$ C.... & $\ldots \ldots$ & $\ldots$ CC . . C. & . A... \\
\hline 70 & $\ldots \mathrm{G}$ & $\ldots \ldots \ldots$ & $\ldots G$ & $\ldots$ A.... & . C.G.... & $\ldots \ldots$ & . C. & A... \\
\hline 71 & C. . G. & & $\ldots G \ldots$. C & $\ldots$. . . . & T.C.... & $\ldots \ldots$ & . CC. & .A... \\
\hline 72 & ГC..G. & $\ldots \ldots \ldots$ & $\ldots \mathrm{G} \ldots \mathrm{CC}$ & $\ldots A \ldots$ & T.C..... & $\ldots \ldots$ & . C. . & . A. . \\
\hline & C. . G. & $\ldots \ldots \ldots$ & $\ldots G \ldots$ C & $\ldots$..... & T.C.... & $\ldots \ldots$ & $\ldots$ C...C. & AG. . \\
\hline 74 & $\ldots G$ & $\ldots \ldots \ldots$ & T...... & $\ldots$ A.... & $\ldots$ C..... & $\ldots \ldots$ & $\ldots$ C...C. & .A... \\
\hline & $\ldots \mathrm{C} \ldots \mathrm{G}$. & $\ldots \ldots$ & $\ldots G \ldots$ & $\ldots$. . . . & $\ldots$ C..... & $\ldots \ldots$ & $\ldots$ C...C. & .A.. \\
\hline 76 & $\ldots \mathrm{C} \ldots \mathrm{G}$ & $\ldots \ldots$. . . & $\ldots G \ldots$. & $\ldots A \ldots$ & $\ldots$ C..... &.$A \ldots$. & . C. . & .A... \\
\hline & $\ldots \mathrm{G}$. & $\ldots \ldots$... & $\ldots G \ldots$. . C & $\ldots$ A.... & $\ldots$ C..... & $\ldots \ldots$ & . C...C. & .A... \\
\hline & $\ldots G$ & $\ldots \ldots \ldots$ & $\ldots$ TG.... & $\ldots$ & $c \ldots . .$. & $\ldots$ & . C. . & A... \\
\hline & $\ldots \mathrm{G}$. & $\ldots$ Т.... & $\ldots G \ldots$. . C & $\ldots$ A. . . & $\ldots$ C..... & $\ldots \ldots$ & . . C. . & .A... \\
\hline 80 & $\ldots \mathrm{C} \ldots \mathrm{G}$ & $\ldots \ldots \ldots$ & $\ldots \mathrm{G} \ldots \mathrm{C}$ & $\ldots$ A.... & $\ldots$ C..... & G...A. . & $\ldots$ C.... C. & $\ldots$ A... \\
\hline & $\ldots \mathrm{G}$. & $\ldots \ldots \ldots$ & $\ldots \mathrm{G} \ldots \mathrm{C}$ & $\ldots A \ldots$ & $\ldots$ C..... & $\ldots A$ & . C...C. & .A... \\
\hline & $\ldots G$ & $\ldots \ldots \ldots$ & $\ldots G$ & $\cdots \cdots$ & $\ldots$ СТ..... & $\ldots$. & . C. . & .A... \\
\hline 33 & $\ldots \mathrm{C} \ldots \mathrm{G}$ & $\ldots \ldots \ldots$ & $\ldots G \ldots C$ & $\ldots A \ldots A$. & $\ldots$ C..... & $\ldots G$ & . C. & $\ldots A \ldots$ \\
\hline 34 & $\ldots \mathrm{G}$. &.$C \ldots \ldots$ & $\ldots G \ldots$ C & $\ldots$ A. . . & $\ldots$ C..... & $\ldots \mathrm{G}$ & . C...C. & .A. . \\
\hline & $\ldots G$ & $\ldots \ldots \ldots$ & $\ldots \mathrm{G} \ldots \mathrm{CC}$ & $\ldots A \ldots$ & $\ldots$ C.... & $\ldots G$ & $\ldots$ C...C. & A. . \\
\hline & .T.G. & $\ldots \ldots \ldots$ & $\ldots G$ & $\ldots A$ & . С... Т. & $\ldots G$ & $\ldots$ C. & . A. . \\
\hline 37 & $\ldots \mathrm{C} \ldots \mathrm{G}$ & $\ldots \ldots \ldots \ldots$ & $\ldots G \ldots C$ & $\ldots A$. & $\ldots$ С... & $\ldots \ldots \mathrm{AT}$ & $\ldots$ C. & .A. \\
\hline & $\ldots G$. & & $\ldots G \ldots C$ & $\ldots$ A.... & . С. С. . . & $\ldots \ldots \mathrm{A}$ & . C. . & $\ldots$ A. \\
\hline & $\ldots \mathrm{GC}$ & $\ldots \ldots \ldots$ & $\ldots G$ & $\ldots A \ldots$ & . С... . & $\ldots \ldots$ & . C.. & A. . \\
\hline & $\ldots \mathrm{C} \ldots \mathrm{G}$ & & $\ldots \mathrm{G} \ldots \mathrm{C}$ & ... A. . . & . C...T. & $\ldots \ldots$ & . C. . & . A. . \\
\hline 91 & $\ldots \mathrm{C} \ldots \mathrm{C}$ & & $\ldots \mathrm{G} \ldots \mathrm{CC}$ & $\ldots$... & $\ldots$ C..... & $\ldots \ldots \mathrm{AT}$ & $\ldots$ C...C. & .A. \\
\hline & $\ldots$ C...G. & & $\ldots G \ldots G C$ & $\ldots A$. & $\ldots C \ldots \ldots$ & $\ldots \mathrm{G}$. & $\ldots \mathrm{C} \ldots \mathrm{C}$ & .A. \\
\hline & $\ldots \mathrm{C} \ldots \mathrm{G}$ & $\ldots \ldots \ldots$ & $\ldots G \ldots$. . C & $\ldots A$ & $\ldots$ C... & $\ldots . c$ & . C. & . A. . \\
\hline $9<>3$ & $\ldots \mathrm{C} \ldots \mathrm{G}$ & c...... & $\ldots \mathrm{G} \ldots \mathrm{CC}$ & $\ldots A$. & . C...T. & .....AT. & $\ldots$ C...C. & .A. \\
\hline-95 & $\ldots \mathrm{C} \ldots \mathrm{G}$. & & $\ldots \mathrm{G} \ldots \mathrm{CC}$ & .T.A. & $\ldots$ С... T. & $\ldots \ldots \mathrm{AT}$ & $\ldots$ C... C. & .A. . \\
\hline & ...G. & & $\ldots G \ldots$. & $\ldots \mathrm{A}$. & . C...TT. & & $\ldots \mathrm{C}$. & . A. . \\
\hline & $\ldots$ C...GG. & $\ldots \ldots \ldots$ & $\ldots$ G...CC & $\ldots$ A.... & . С... T. & $\ldots \ldots$ & $\ldots$ C... C. & $\ldots$ A. \\
\hline $1-98$ & $\ldots$ C...G. & $\ldots \ldots \ldots$ & $\ldots \mathrm{G} \ldots \mathrm{CC}$ & . .А. . & . С... & ....АТ & G.C...C. & . A. \\
\hline
\end{tabular}




\section{Appendix 2}

Distribution of haplotypes detected in 18 waterholes for M. australiense within the Lake Eyre basin. For site designation, refer to Figure 1. Catchments: Bulloo (B), Cooper (C), Diamantina (D) and Georgina (G) are shown in Table A2.

\section{Appendix 3}

Distribution of haplotypes detected for $M$. australiense within the Murray-Darling basin. For site designation, refer to Figure 1. Catchments: Warrego (W), Paroo (P), Balonne-Condomine (BC) and Border Rivers (BR) are shown in Table A3.

Table A2

\begin{tabular}{|c|c|c|c|c|c|c|c|c|c|c|c|c|c|c|c|c|c|}
\hline Catchments sites & $B$ & $C$ & $C$ & C & C & C & C & $D$ & $D$ & $D$ & $D$ & $D$ & $D$ & $G$ & $G$ & $G$ & $G$ \\
\hline Haplotypes & 10 & 14 & 13 & 15 & 11 & 12 & 16 & 20 & 30 & 21 & 19 & 18 & 17 & 22 & 25 & 24 & 23 \\
\hline H1 & & & & & & & & & & & & & & 1 & & & \\
\hline $\mathrm{H} 2$ & 2 & 2 & & & & & & 9 & 2 & 7 & 12 & 5 & 6 & 8 & 7 & 9 & 10 \\
\hline H3 & & & & & & & & & & & & & & & 1 & & \\
\hline H4 & & & & & & & & & & & 1 & & 1 & & & & \\
\hline H5 & & & & & & & & & & & & & & & 1 & 1 & \\
\hline H6 & & & & & & & & & & & 1 & & & & & & \\
\hline H7 & & & & & & & & & & & & & 1 & & & & \\
\hline H8 & & & & & & & & & & 1 & & & & & & & \\
\hline H9 & & & & & & & & & & & & & & 1 & & & \\
\hline H10 & & & & & & & & & & & & & & & 1 & & \\
\hline H11 & & & & & & & & 2 & & 1 & 1 & 1 & & & & & \\
\hline H12 & & & & & & & & 1 & & 1 & & & & & & & \\
\hline $\mathrm{H} 13$ & & & & & & & & & & & 1 & & & & & & \\
\hline H14 & & & & & & & & & & & 1 & & & & & & \\
\hline H15 & 1 & & & & & & & & & & & & & & & & \\
\hline H16 & 4 & & & & & & & & & & & & & & & & \\
\hline H17 & 1 & & & & & & & & & & & & & & & & \\
\hline H18 & & & & & & & & 1 & 2 & 3 & 3 & 1 & 1 & & & & \\
\hline H19 & & & & & & & & & 2 & 2 & & & 1 & & & & \\
\hline $\mathrm{H} 20$ & & & & & & & & & & 1 & & & & & & & \\
\hline H21 & & & & & & & & 1 & & & & & & & & & \\
\hline $\mathrm{H} 22$ & & & & & & & & 1 & & 1 & & 1 & & & & & \\
\hline $\mathrm{H} 23$ & & & & & & & & 2 & & 2 & & & & & & & \\
\hline $\mathrm{H} 24$ & 1 & & & & & & & & & & & & & & & & \\
\hline $\mathrm{H} 25$ & & & & & & & & & 1 & & & 1 & 1 & & & & \\
\hline H26 & & & & & & & & 2 & 1 & 1 & & 1 & & & & & \\
\hline $\mathrm{H} 27$ & & 2 & & & & & & & & & & & & & & & \\
\hline $\mathrm{H} 28$ & & & 1 & & & & & & & & & & & & & & \\
\hline $\mathrm{H} 29$ & & & 1 & 5 & & & & & & & & & & & & & \\
\hline H30 & & & & & 2 & & & & & & & & & & & & \\
\hline H31 & & & 1 & & & & & & & & & & & & & & \\
\hline H32 & & 2 & & 2 & & & & & & & & & & & & & \\
\hline H33 & & & & 2 & & & & & & & & & & & & & \\
\hline H34 & & & & 1 & & & & & & & & & & & & & \\
\hline H35 & & & & & & 1 & & & & & & & & & & & \\
\hline H36 & & 1 & & & & & & & & & & & & & & & \\
\hline H37 & & 11 & 13 & 9 & 14 & 5 & & & & & & & & & & & \\
\hline H38 & & & & & & & 3 & & & & & & & & & & \\
\hline H39 & & & & & & & 1 & & & & & & & & & & \\
\hline $\mathrm{H} 40$ & & & & & & & 1 & & & & & & & & & & \\
\hline H41 & & & & & 1 & & & & & & & & & & & & \\
\hline H42 & & & & & & & 1 & & & & & & & & & & \\
\hline $\mathrm{H} 43$ & & 2 & 1 & & & & & & & & & & & & & & \\
\hline H45 & & & & & 2 & & & & & & & & & & & & \\
\hline $\mathrm{H} 46$ & & & & & 2 & & & & & & & & & & & & \\
\hline $\mathrm{H} 47$ & & & 2 & 1 & & & & & & & & & & & & & \\
\hline H48 & & & 2 & & & & & & & & & & & & & & \\
\hline H49 & & 1 & & & & & & & & & & & & & & & \\
\hline H50 & & & & & & 1 & & & & & & & & & & & \\
\hline H51 & & & & & & & & 1 & & & & & & & & & \\
\hline
\end{tabular}


Table A3

\begin{tabular}{|c|c|c|c|c|c|c|c|c|c|c|c|c|c|}
\hline Catchments sites & $W$ & $W$ & $W$ & $W$ & $W$ & $P$ & $P$ & $B C$ & $B C$ & $B R$ & $B R$ & $B R$ & $B R$ \\
\hline Haplotypes & 4 & 6 & 5 & 7 & 3 & 8 & 9 & 1 & 2 & 26 & 29 & 28 & 27 \\
\hline H52 & & & & & & & 1 & & & & & & \\
\hline H53 & & & & & & & & & & & & 1 & 2 \\
\hline H54 & & & & & & & & 1 & & & & & \\
\hline H55 & & & & & & & & & & & 1 & & 1 \\
\hline H56 & & & & & & & & & & & 1 & & \\
\hline H57 & & & & & & & & & & & 1 & & \\
\hline H58 & & & & 2 & & & & & & & & & \\
\hline H59 & & & 1 & & & & & & & & & & \\
\hline H60 & & & & & & & & & & 2 & 1 & 1 & 1 \\
\hline H61 & & & & 1 & & & & & & & & & \\
\hline H62 & 1 & & & & & & & & & & & & \\
\hline H63 & & & & & & & & & & 1 & & & \\
\hline H64 & & & & & & & & & 1 & & & & \\
\hline H65 & & & 2 & & & & & & & & & & \\
\hline H66 & & & 12 & & & & & & & & & & \\
\hline H67 & & & 1 & & & & & & & & & & \\
\hline H68 & & & 1 & & & & & & & & & & \\
\hline H69 & & & 1 & & & & & & & & & & \\
\hline H70 & & & 3 & & & & & & & & & & \\
\hline H71 & & & 1 & & & & & & & & & & \\
\hline H72 & & & 1 & & & & & & & & & & \\
\hline H73 & & & & & 1 & & & & & & & & \\
\hline H74 & & 1 & & 2 & & 1 & 5 & & & & & & \\
\hline H75 & & & & & & & & & & 1 & & & \\
\hline H76 & 2 & & & 1 & & & & 5 & 5 & 3 & & 3 & 3 \\
\hline H77 & & & & & & & & & & & 1 & & \\
\hline H78 & & & & & & & & & 1 & & 1 & 1 & \\
\hline H79 & & & & & & & & & & & & 1 & \\
\hline H80 & & & & & & & & 1 & & & & & \\
\hline H81 & & & & 1 & & & & & & & & & \\
\hline H82 & 1 & & & 2 & & & & 1 & & & & & \\
\hline H83 & & 1 & & & & & & & & & & & \\
\hline H84 & & 4 & & & & & & & & & & & \\
\hline H85 & & & & & & & & & & & 1 & 1 & \\
\hline H86 & 1 & & & & & & & & & & & & \\
\hline H87 & 1 & 1 & & 3 & 1 & & & & 1 & & & & \\
\hline H88 & & & & & & 1 & 2 & & & & & & \\
\hline H89 & & & & & & & & & & 1 & & & \\
\hline H90 & 7 & 8 & & 8 & 8 & & 4 & & 1 & 2 & 3 & 3 & 2 \\
\hline H91 & & & & & & & 2 & & & & & & \\
\hline H92 & & & & & & & & & & & & 1 & \\
\hline H93 & & & & & & & & & & & & & 1 \\
\hline H94 & & & & & & & & & & 1 & & & \\
\hline H95 & & & & & & & & & & & & 1 & \\
\hline H96 & & & & & & & & & & & & & 1 \\
\hline H97 & & & & & & & & & & 1 & 1 & 1 & \\
\hline H98 & & & & & & & 1 & & & & & & \\
\hline
\end{tabular}

